\title{
EFEKTIVITAS PELAYANAN PUBLIK PADA UNIT PELAKSANA TEKNIS DINAS KEPENDUDUKAN DAN PENCATATAN SIPIL KABUPATEN TIMOR TENGAH SELATAN PROVINSI NUSA TENGGARA TIMUR
}

\author{
Oleh \\ Ismael Halla ${ }^{1}$, \\ Lenny Tamunu ${ }^{2}$, Nursalam ${ }^{3}$ \\ ${ }^{1}$ Mahasiswa Program Pascasarjana Universitas Nusa Cendana Kupang \\ halla.ismael@gmail.com \\ ${ }^{2,3}$ Fakultas Ilmu Sosial dan Ilmu Politik Universitas Nusa Cendana Kupang
}

\begin{abstract}
In this paper the author wants to highlight the problem of service effectiveness and its inhibiting factors. The research method used is qualitative social science research to measure the UPTD in implementing services effectively and efficiently according to the establishment of the UPTD based on TTS Regent Regulation Number 15 of 2011 concerning the Organization and Work Procedures of Disdukcapil Technical Operators. Input of data, processes and output in the UPTD of Disdukcapil in five sub-districts is still very much needed by human resources, because the number is still very small so that responsiveness is not sufficient. Still constrained by service procedures, enthusiasm for collaboration and work group loyalty, infrastructure facilities, accuracy, style of service delivery.

The results showed that the Quality of Birth Certificate Service at the UPTD had not been fully fulfilled. The supporting factors: Budget that is not adequate. Government commitment according to the work plan has not been effective, the number of human resources is still very lacking. Regional Regulation Policies that have not rationally understood the conditions of the service area. Inhibiting factors in the form of facilities and infrastructure, work culture and services, public awareness, and employee discipline. It is expected that with the assessment of performance, all inhibited causes will be controlled.
\end{abstract}

Keywords: service effectiveness, birth certificate, UPTD

\section{ABstrak}

$\mathrm{D}$ alam tulisan ini penulis ingin menyoroti masalah efektivitas pelayanan dan faktor-faktor penghambatnya. Metode penelitian yang digunakan adalah penelitian ilmu sosial secara kualitatif untuk mengukur UPTD dalam melaksanakan pelayanan secara efektif dan efisien sesuai pembentukan UPTD berdasarkan Peraturan Bupati Timor Tengah Selatan ( TTS) Nomor 15 Tahun 2011 tentang Organisasi dan Tata Kerja Pelaksana Teknis Disdukcapil. Input data, proses dan output di UPTD Disdukcapil di lima wilayah kecamatan masih sangat dibutuhkan sumber daya manusia, sebab jumlahnya masih sangat sedikit sehingga responsivitas belum memadai. Masih terkendala oleh prosedur pelayanan, semangat kerja sama dan loyalitas kelompok kerja, sarana prasarana, kecermatan, gaya pemberian layanan. 
Hasil penelitian menunjukkan bahwa Kualitas Layanan Akta Kelahiran di UPTD belum terpenuhi secara maksimal. Adapun faktor Pendukungnya: Anggaran yang belum memadai. Komitmen Pemerintah sesuai rencana kerja belum efektif, sumber daya manusia yang jumlahnya masih sangat kurang. Kebijakan Peraturan Daerah yang belum rasional memahami kondisi wilayah pelayanan. Faktor Penghambat berupa Sarana dan Prasarana, Budaya kerja dan pelayanan, Kesadaran Masyarakat, dan Kedisiplinan Pegawai. Diharapkan dengan adanya penilaian kinerja maka semua penyebab yang menghambat dapat dikendalikan.

Kata kunci: efektivitas pelayanan, akta kelahiran, UPTD

\section{PENDAHULUAN}

Denelitian ini lebih memfokuskan untuk kepemilikan akta kelahiran sesuai dengan Permendagri No. 19 Tahun 2016 tentang Percepatan Peningkatan Persentase Kepemilikan Akta Kelahiran. Kebijakan ini berlaku untuk seluruh wilayah atau daerah yang berada di bawah pemerintahan negara Indonesia, termasuk Kabupaten Timor Tengah Selatan. Kabupaten Timor Tengah Selatan. memiliki luas wilayah 3.929 $\mathrm{km}^{2}$ yang terdiri dari 32 Kecamatan, 12 Kelurahan dan 266 Desa dengan jumlah penduduk 477.072 jiwa (Dinas Dukcapil Kabupaten Timor Tengah Selatan/TTS, 2018).

Tentu dalam menjawab maksud tersebut di atas dengan memperhatikan luas wilayah, jumlah penduduk, sarana prasarana penunjang, infrastruktur yang belum memadai dan untuk menjawab kebutuhan masyarakat terhadap hak sipil dengan mendekatkan pelayanan kepada masyarakat, Pemerintah Kabupaten TTS dalam hal ini Disdukcapil telah melakukan berbagai terobosan, salah satunya adalah membentuk lima UPTD dan mendelegasikan sebagian urusan tugas kewenangan pelayanan administrasi kependudukan dari Disdukcapil kepada UPTD di lima kecamatan.

Unit Pelayanan Teknis (UPT) Disdukcapil Kabupaten TTS mempunyai tugas membantu Dinas dalam melaksanakan kegiatan teknis operasional yang secara langsung berhubungan dengan pelayanan kepada masyarakat dan kegiatan yang mendukung pelaksanaan sebagian tugas teknis pembinaan dan pendataan administrasi, pencatatan pendaftaran penduduk dan melakukan pelayanan di bidang pencatatan sipil sesuai bidang kewenangan yang dilimpahkan antara lain Penerbitan Kartu Keluarga, Penerbitan Kutipan Akta Kelahiran, Kutipan Akta Perkawinan, Kutipan Akta Kematian dan Kutipan Akta Perceraian.

Dari keempat jenis pelayanan yang disebutkan di atas, peneliti hanya akan melakukan penelitian terhadap jenis pelayanan penerbitan kutipan akta kelahiran dengan alasan bahwa akta kelahiran merupakan salah satu bentuk kepedulian pemerintah terhadap hak-hak anak, juga sebagai respons terhadap Permendagri Nomor 19 Tahun 2016 yang salah satu tujuannya adalah meningkatkan cakupan akta kelahiran anak. Selain itu dokumen akta kelahiran sangat dibutuhkan pada saat seseorang mendaftar di sekolah mulai dari Pendidikan Anak Usia Dini (PAUD), pada saat mencari pekerjaan, dan pada saat urusan pernikahan dan lain-lain. Sedangkan KTP, KK dan akta perkawinan akan diurus ketika seseorang sudah dewasa, misalnya untuk mendapatkan KTP harus berusia minimal 17 tahun 1 hari.

Fenomena di lapangan menunjukkan bahwa hingga saat ini masih banyak warga masyarakat yang belum memperoleh dokumen kependudukan sekalipun sangat dekat dengan UPT Disdukcapil di setiap daerah pelayanan administrasi 
Tabel 1 Data Warga Masyarakat yang belum Memperoleh Akta Kelahiran

\begin{tabular}{|c|c|c|c|c|c|c|c|}
\hline \multirow[t]{2}{*}{ No. } & \multirow[t]{2}{*}{$\begin{array}{l}\text { Wilayah UPTD } \\
\text { Disdukcapil }\end{array}$} & \multicolumn{3}{|c|}{ Jumlah Penduduk } & \multicolumn{3}{|c|}{$\begin{array}{c}\text { Yang belum memperolah } \\
\text { Akta kelahiran } \\
\end{array}$} \\
\hline & & 2016 & 2017 & 2018 & 2016 & 2017 & 2018 \\
\hline 1. & Kec. Mollo Utara & 65,993 & 62,744 & 65,288 & 57,706 & 48,212 & 41,105 \\
\hline 2. & Kec. Amanuban Tengah & 61,649 & 60,938 & 62,460 & 54,481 & 47,755 & 42,010 \\
\hline 3. & Kec. Amanuban Selatan & 100,761 & 97,425 & 100,760 & 90,054 & 65,628 & 67,401 \\
\hline 4. & Kec. Amanuban Timur & 67,058 & 64,857 & 67,150 & 60,919 & 53,523 & 46,488 \\
\hline 5. & Kec. Amanatun Selatan & 94,456 & 94,192 & 97,105 & 83,180 & 74,475 & 66,524 \\
\hline
\end{tabular}

Sumber: Kantor Disdukcapil Kab. TTS, 2019.

kependudukan. Melalui penelitian ini penulis hanya menampilkan khusus data akta kelahiran yang telah diperoleh maupun yang belum memperoleh pada setiap kecamatan yang ditugaskan untuk melakukan pelayanan akta pencatatan sipil. Penulis juga dapat menguraikan data penduduk di setiap wilayah UPTD Disdukcapil pada setiap kecamatan di Kabupaten TTS adalah sebagaimana tampak pada Tabel 1.

Sesuai data pada Tabel 1 di atas menunjukkan bahwa masih banyak warga masyarakat yang belum memperoleh akta kelahiran. Jumlah tersebut setiap tahun bertambah banyak dan sedikit sekali warga yang mengurus administrasi akta kelahirannya. Apabila dikaji secara seksama maka pelayanan administrasi kependudukan yang dilakukan di UPT Disdukcapil Kabupaten TTS khususnya pembuatan akta kelahiran belum efektif.

Pengamatan awal penulis bahwa penyebabnya juga faktor secara internal (DisdukcapildanUPTD) untukmenumbuhkan dan meningkatkan kinerja aparatur dalam memberikan pelayanan publik. Sedangkan secara eksternal hal tersebut datangnya dari kesadaran masyarakat tentang pentingnya kepemilikan dokumen kependudukan yang merupakan hak dasar sebagai warga negara. Berdasarkan uraian latar belakang di atas, maka permasalahan dalam penelitian ini dapat dirumuskan, yakni (1). Bagaimana efektivitas pelayanan publik pada UPT Disdukcapil Kabupaten TTS? (2). Faktor-
Faktor apa saja yang menghambat dan mendukung pelaksanaan pelayanan publik pada UPT Disdukcapil Kabupaten TTS?

\section{METODE PENELITIAN}

Penulis menggunakan pendekatan deskriptif, yaitu pendekatan penelitian yang hanya berusaha menggambarkan secara jelas dan sekuensial terhadap pertanyaan penelitian yang telah ditentukan sebelum peneliti terjun ke lapangan dan peneliti tidak menggunakan hipotesis sebagai petunjuk arah atau guide dalam penelitian (Sukardi, 2010:14).

Alasan penulis memilih jenis penelitian kualitatif dengan pendekatan deskriptif adalah sesuai dengan tujuan penelitian, yaitu untuk mengetahui dan mendeskripsikan efektivitas pelayanan publik pada UPT Disdukcapil Kabupaten TTS.

\section{PEMBAHASAN}

\section{Unit Pelaksanaan Teknis (UPTD) Disdukcapil Kabupaten TTS}

Sesuai Peraturan Bupati TTS Nomor 15 Tahun 2011 tentang Unit Pelaksana Teknis Disdukcapil Kabupaten TTS, dengan memperhatikan kondisi wilayah yang sangat luas dan jumlah penduduk yang sangat banyak maka demi mendekatkan pelayanan kepada masyarakat telah dibentuk lima wilayah UPT Disdukcapil di wilayah Kabupaten TTS. Semua Kantor UPT Disdukcapil Kabupaten TTS hanya sebagai 
perpanjangan kerja Kantor Disdukcapil Kabupaten TTS, sehingga semua urusan pelayanan harus memberikan laporan dan pertanggungjawaban kepada kantor induknya. Dengan demikian Peraturan Bupati tersebut hanya untuk membantu urusan pelayanan dari Kantor Disdukcapil Kabupaten TTS, artinya bukan berdiri sendiri tanpa melakukan koordinasi dan pertanggungjawaban kepada kantor induk.

Segala pelayanan di wilayah UPT Disdukcapil Kabupaten TTS hanya untuk menjalankan segala urusan pelayanan yang berkaitan dengan pelayanan Disdukcapil Kabupaten TTS telah memberikan pelayanan untuk: pertama, Bidang Pelayanan Pendaftaran Penduduk yang meliputi (a) Pelayanan Kartu Keluarga (KK); (b) Pelayanan Kartu Tanda Penduduk Elektronik (KTP-el). Kedua, Bidang Pelayanan Pencatatan Sipil terdiri dari (a) Pelayanan Akta Perkawinan Non Muslim; (b) Pelayanan Akta Kelahiran; (c) Pelayanan Akta Kematian; (d) Pelayanan Akta Perceraian Non Muslim.

Sesuai ketentuan Pasal 5 Perbup TTS Nomor 15 Tahun 2011, bahwa fungsi UPTD Disdukcapil di wilayah cakupan (1) pelaksanaan teknis pencatatan sipil dan pendaftaran penduduk; (2) pengumpulan dan penyediaan data sesuai lingkup bidang tugas di wilayah delegasinya; (3) pembinaan dan pelaksanaan tugas teknis operasional pelayanan sesuai dengan bidangnya di wilayah sekitarnya; (4) penyelenggaraan dan pelaksanaan koordinasi pembinaan pelaksanaan kegiatan di wilayah sekitarnya; (5) penyelenggaraan dan pelaksanaan koordinasi pembinaan pelaksanaan kegiatan di wilayah atau lokasinya; (6) Penyelenggaraan kegiatan teknis administrasi kependudukan dan pencatatan sipil; (7) pengelolaan dan pembinaan ketatausahaan UPTD; dan (8) Penyedia data pencatatan penduduk untuk diolah dan disampaikan kepada dinas.
Susunan organisasi UPT Disdukcapil terdiri dari kepala UPT; kepala sub tata usaha; bendahara penerimaan dan penyetor, petugas pencatatan sipil, petugas pengolahan data dan informasi administrasi kependudukan dan kelompok fungsional. UPTD dipimpin oleh seorang kepala yang berada di bawah dan bertanggung jawab kepada kepala dinas sebagai instansi induk, sedangkan secara teknis dan taktis dalam operasional berada di bawah koordinasi camat tempat kedudukan UPTD. Jumlah petugas di setiap UPTD disesuaikan dengan kebutuhan unit sesuai dengan ketentuan peraturan perundang-undangan.

Tata kerja UPT dimaksud, yakni dalam melaksanakan tugasnya kepala UPTD, Kepala sub bagian tata usaha, bendahara penerima atau penyetor, petugas pencatatan sipil dan pendaftaran penduduk, petugas pengolahan data dan informasi kependudukan wajib menerapkan prinsip koordinasi, integrasi, dan sinkronisasi baik dalam lingkungan masing-masing maupun antar unit organisasi di lingkungan pemerintah daerah Kabupaten TTS sesuai dengan bidang tugasnya. Kepala UPTD bertanggung jawab memimpin dan mengoordinasikan bawahan dan memberikan bimbingan serta petunjuk bagi pelaksanaan tugas bawahan. Kepala UTPD wajib mengawasi dan bila terjadi penyimpangan agar mengambil langkah-langkah yang diperlukan sesuai dengan ketentuan peraturan perundangundangan.

Sesuai data yang diperoleh bahwa setiap UPT Disdukcapil Kabupaten TTS tidak semua mempunyai kepala UPT. Hal ini juga menjadi kendala dalam mengatur segala pelayanan yang ada pada setiap UPT. Misalnya di UPT Disdukcapil Kec. Amanuban Selatan tidak ada kepala UPT seperti yang lainnya. Sementara di UPT Disdukcapil Kecamatan Amanuban Tengah dipimpin oleh Yohana Lahea, UPT Disdukcapil Amanuban Timur dipimpin oleh Yunus Bana, UPT Disdukcapil Amanatun Selatan dipimpin oleh Yumina Benu, dan 
UPT Disdukcapil Mollo Utara dipimpin oleh Febi Pobas.

Selain tidak ada pimpinan UPT juga tidak ada Kepala Sub Bagian Tata usahanya, seperti di UPT Cakupan Wilayah Mollo Utara, juga tidak ada Bendahara Penerima/Penyetor dan tidak ada Petugas Pengolahan Data dan Informasi Administrasi kependudukan, tentu efektivitas pelayanan menjadi tersendat seperti pada wilayah cakupan UPT Disdukcapil Mollo Utara. Sementara itu, di UPT Disdukcapil wilayah cakupan Amanatun Selatan tidak ada Petugas Pengelolaan data dan Informasi Administrasi Kependudukan dan Bendahara Penerima/penyetor. Sedangkan pada wilayah cakupan Kecamatan Amanuban Selatan kekurangan petugasnya seperti pada wilayah cakupan Mollo Utara.

Selain kekurangan yang ada, sangat memprihantinkan lagi pada wilayah cakupan UPT Disdukcapil Amanuban Selatan, sebab selain tidak ada kepala UPT-nya juga tidak ada Bendahara Penerima/Penyetor, tidak ada juga petugas Pencatatan Sipil, dan tidak Petugas Pengelolaan Data dan informasi administrasi kependudukan sehingga yang ada Kepala Sub Bagian Tata Usahanya merangkap Kepala UPT, dan semua unsur dalam pelaksanaan pelayanan. Berbeda dengan UPT Disdukcapil pada wilayah cakupan Amanuban Tengah hanya terdapat tiga orang, yakni Kepala UPT, Kasubag dan Petugas Pencatatan Sipil, sementara Bendahara Penerima/penyetor dan Petugas Pengelolaan Data dan Informasi administrasi kependudukan tidak ada petugas.

\section{Efektivitas Pelayanan Akta Kelahiran pada Kantor UPTD Disdukcapil TTS}

Produktivitas UPTD Disdukcapil Kabupaten TTS memiliki input yang mendukung produktivitas kerja. Input data yang dimaksud adalah data base kependudukan sebagai salah satu bagian input terpenting pada saat proses pembuatan akta kelahiran yang akan dilakukan.
Sebagaimana dikatakan oleh aparatur Kepala Bidang Pelayanan Pencatatan Sipil Dinas Kependudukan dan Pencatatan Sipil Kabupaten TTS, yakni Meryana M.E Tse saat diwawancarai Penulis pada 12 Februari 2019 menyatakan bahwa:

"Kita menggunakan proses input dari data berawal, sehingga dari setiap UPTD di wilayah kecamatan yang ada, dan sesuai Peraturan Bupati TTS No. 15 Tahun 2015 dibenktulah UPTD di lima wilayah kecamatan yang bertugas sebagai perpanjangan tangan dinas guna membantu input data kependudukan termasuk data akta kelahiran. Data tersebut masih dianggap sebagai data awal untuk diverifikasi guna memastikan validasi terakhir setelah dimutakhirkan pada pangkalan data pada dinas. Memang selama ini di Dinas Dukcapil Kab. TTS sudah ada aplikasi khusus, yaitu Sistem Informasi Administrasi Kependudukan (SIAK) untuk mengiput data, namun karena keterbatasan jaringan, maka aplikasi tersebut belum bisa difungsikan di UPTD sehingga proses pelayanan dokumen di UPTD masih dilakukan secara ofline (manual). Oleh karenanya ke depan kita perlu jaringan yang memadai sehingga aplikasi tersebut bisa difungsikan di UPTD guna mengakses data secara valid untuk memastikan data kependudukan yang tersedia seperti pada daerah lain."

Berdasarkan hasil wawancara pada 13 Februari 2019 dengan Petugas input data di UPTD Kecamatan Amanuban Tengah Yohana Lahea, dalam penjelasannya bahwa:

"Semua data di-input secara manual dan operator antar ke kantor induk untuk di-input lagi sehingga bisa menentukan kepastian data kependudukan. Artinya syarat utama dari input data secara manual bagi pengurusan akta kelahiran adalah nama anggota itu harus telah ada dalam anggota keluarga atau kartu 
keluarga, sebab untuk memperoleh petikan akta kelahiran harus ada Nomor Induk Kependudukan (NIK) pada kartu keluarga".

Kasubag Tata Usaha di UPTD wilayah Kecamatan Amanuban Tengah, yakni Paul M.M. Mota, dalam penjelasannya Tanggal 13 Februari 2019 bahwa:

"Khusus pembuatan akta kelahiran infarstruktur yang digunakan sebagai sarana penunjang dari pembuatan akta kelahiran adalah dilakukan input data secara manual. Sebenarnya sudah ada aplikasi khusus guna memvalidasi data yang di-input, namun belum ada jaringan internet yang memadai di UPTD sehingga proses validasi data harus dilakukan di Dinas Dukcapil Kabupaten. Hal ini menyebabkan warga harus menunggu paling lama satu minggu untuk memperoleh data di kantor induk di Kota Kabupaten TTS, sehingga biasanya harus terkumpul paling lama satu minggu baru bisa diproses. Ketekunan warga untuk mempersiapkan data pendukung pun sangat dibutuhkan guna memvalidasi data yang akan diinput."

Berdasarkan penjelasan di atas maka suatu produktivitas yang dilaksanakan dari Dinas Kependudukan dan Pencatatan Sipil dilihat dari produktifnya dinilai cukup baik dan dapat dikatakan pencapaian input dengan infrastruktur yang dibutuhkan membuat suatu produktivitas yang baik. Hasil wawancara pada 13 Februari 2019 dengan Kepala UPTD di wilayah Kecamatan Amanuban Tengah, yakni Paul M.M. Mota, juga menyebutkan bahwa:

"Selama kurun waktu yang tersedia, seluruh masyarakat berkewajiban untuk memenuhi seluruh syarat dan ketentuan yang harus dipenuhi sebelum dilakukan pembuatan secara faktual oleh Dinas Kependudukan dan Pencatatan Sipil Kabupaten TTS sebagai tindak lanjut dari persyaratan yang telah diberikan oleh UPTD, input akan terjadi ketika semua data-data pendaftar akta kelahiran dimasukkan ke dalam data induk di dinas."

Sesuai hasil wawancara pada 10 Februari 2019 dengan Petugas penginput data pada Kantor Dinas Kependudukan dan Pencatatan Sipil Kabupaten TTS, yakni Paulina Tamelan menyebutkan bahwa:

"Dengan adanya aplikasi SIAK sangat memudahkan operator dalam melakukan input data dokumen kependudukan termasuk di dalamnya akta kelahiran."

Berdasarkan penjelasan mengenai operator pangkalan data induk di Kantor Dinas Kependudukan dan Pencatatan Sipil Kabupaten TTS sebagaimana diminta pendapatnya Tanggal 10 Februari 2019, yakni Octavia Nomleni menyatakan bahwa:

"Dalam pelaksanaan pemasukan datadata akta kelahiran, maka Kementerian Dalam Negeri melalui Ditjen Dukcapil memberikan sarana aplikasi baru dalam pendataan pada bidang pencatatn sipil termasuk akta kelahiran di Dinas Kependudukan dan Pencatatan Sipil Kabupaten TTS. Aplikasi tersebut, yaitu SIAK (Sistem Informasi Aplikasi Kependudukan). Aplikasi ini adalah aplikasi yang hampir sama dengan CASS, namun ini dibuat lebih lengkap dan inovasi terbaru dalam tampilan aplikasinya. Dengan adanya SIAK ini, maka pendataan akta kelahiran lebih mudah dan cepat dari sebelumnya."

Aplikasi SIAK telah membantu mempercepat jalannya pendataan, prosesnya, yaitu hanya dengan memasukkan data sesuai dengan data-data akta kelahiran yang masuk sebelumnya dan selanjutnya disimpan dan secara otomatis akan tersimpan dengan aman,dan ketika dicari pun tinggal memasukkan nomor angka 
ataupun nama pendaftar akta kelahiran tersebut, maka data-dari seseorang tersebut akan muncul secara lengkap.

Menurut Kepala Sub Bagian Pendataan dan Informasi Kantor Dinas Kependudukan dan Pencatatan Sipil Kabupaten TTS, yang diwawancarai pada 18 Februari 2019, yakni Esti S. Tunliu menyatakan bahwa:

"Ukuran kualitas pelayanan tercermin dalam lingkungan internal yang kondusif, yakni lewat pemberdayaan, delegasi wewenang, saling percaya, komunikasi yang efektif, dan sebagainya serta implementasi total human reward termasuk dalam bentuk finansial insentif berupa gaji, bonus, kenaikan gaji, maupun non finansial seperti pujian, kesempatan mengikuti pendidikan, dan pelatihan tambahan."

Sesuai hasil wawancara pada 20 Februari 2019 dengan aparatur UPTD Dinas Kependudukan dan Pencatatan Sipil di wilayah Kecamatan Mollo Utara, yakni Febi Pobas beliau menjelaskan bahwa:

"Kualitas sumber daya manusia yang ada sangat kurang. Khususnya aparatur di setiap UPTD, sebab ada UPTD yang tidak ada pemimpinnya, yang berarti itu hanya sebagai agen pengumpul data di setiap wilayah sehingga keadaan itu membuat warga masyarakat untuk tidak mudah mengurusnya melalui wilayah kecamatan. Dikatakan kurang aparatur karena di wilayah Kecamatan Mollo Utara hanya terdapat dua orang pengurus sehingga tentu harus dikatakan itu hanya sebagai agen pengumpul data kalau masyarakat ingin mengurus data kependudukannya."

Sesuai hasil wawancara pada 18 Februari 2019 dengan Kepala Dinas Disdukcapil Kabupaten TTS, yakni Semuel L.I. Fallo beliau menjelaskan bahwa:

"Realisasi kita memang dalam hal pelayanan kepada masyarakat perlu untuk ditingkatkan. Optimalisasi pelayanan ini akan sangat berpengaruh terhadap kinerja aparat Pemerintah Daerah dan kredibilitas dari aparat itu sendiri. Sehingga peningkatan pelayanan mutlak diperlukan agar kinerja organisasi akan berjalan dinamis".

Berdasarkan pendapat sejumlah informan di atas, maka untuk meningkatkan sumber daya aparatur maka usaha-usaha yang dilakukan di antaranya adalah mengirim aparat untuk mengikuti berbagai jenis pendidikan dan pelatihan dan seminarseminar agar terjadinya suatu peningkatan yang signifikan pada tataran aparat itu sendiri. Sebab telah terukur dengan adanya tingkat disiplin aparatur hadir tepat waktu aparatur UPTD Disdukcapil merupakan suatu kendala yang harus dibenahi. Namun hal ini sangat berhubungan dengan tingkat disiplin masing-masing aparat.

\section{Faktor Pendukung}

\section{a. Anggaran}

Jumlah anggaran yang dialokasikan untuk setiap UPT dari pagu anggaran Dinas Kependudukan dan Catatan Sipil Kabupaten TTS sejak tahun 2016 dan setiap tahunnya dalam hal pembuatan administrasi kependudukan, yaitu senilai Rp277.808.900,00 (dua ratus tujuh puluh tujuh juta delapan ratus ribu delapan ribu sembilan ratus rupiah).

Sekalipun biaya itu dianggap masih kurang namun dengan berbagai cara berkaitan dengan penghematan anggaran semua pelayanan dapat berjalan dengan baik dan memberikan kepuasan bagi warga masyarakat.

\section{b. Komitmen Pemerintah}

Komitmen dari pemerintah, yakni dalam hal ini Bupati dan Wakil Bupati melalui visi dan misi kepemimpinannya merupakan satu poin pendukung dalam menata keseriusan daerah dalam menciptakan kondisi 
pelayanan publik yang lebih terarah demi tercapainya kondisi kemasyarakatan yang lebih baik.

Pemerintah daerah (Bupati dan wakil bupati) bekerja sama dengan instansi dalam hal ini UPTD dan Disdukcapil Kabupaten TTS dalam upaya mewujudkan visi dan misi, maka pemerintah berkewajiban untuk memenuhi kebutuhan seluruh lapisan masyarakat dengan menciptakan sistem pemerintah yang mampu mendukung terciptanya penyelenggaraan pelayanan publik yang prima dan berkesinambungan sesuai dengan kondisi dan mampu menanggapi terjadinya perubahan dimensi serta dampak kompleksitas saat ini. Untuk mendukung percepatan peningkatan kualitas pelayanan publik yang prima pada pemerintah diperlukan komitmen yang kuat, kreativitas, dan langkah-langkah inovasi.

\section{c. Sumber Daya Manusia}

Hal ini menjadi pendukung besar dalam pelayanan publik yang ada di Dinas. Sumber daya manusia sangat penting sebab dia adalah pelaku atau dalam hal ini penyedia layanan jika dalam proses penataan organisasi sumber daya manusia yang tersedia masih sangat minim dari segi kecakapan dan profesionalisme kerja maka akan lahir juga disorientasi sebab bagaimana sebuah kemaksimalan tercapai jika sumber daya yang tersedia tidak memiliki kredibilitas di dalamnya, apakah sumber daya yang tersedia mampu untuk menangkap sembilan prinsip pelayanan publik seperti profesional, efektif, sederhana, transparan, terbuka, tepat waktu, resposnsif tentu saja itu bukan pekerjaan yang mudah.

Untuk meningkatkan pelayanan di UPTD Disdukcapil Kabupaten TTS harus didukung dengan SDM yang memadai, baik dari segi kuantitas maupun kualitas.

\section{d. Kebijakan Peraturan Daerah}

Terlaksananya pelayanan publik juga tidak luput dari pengaruhi kebijakan yang sudah dibuat dalam bentuk peraturan daerah. Kebijakan tersebut selanjutnya menjadi acuan bagi seluruh instansi yang ada di Kabupaten TTS untuk membuat suatu perencanaan kegiatan/program yang akan dilaksanakan.

Kebijakan dalam bentuk pertaturan daerah sangat membantu terlaksananya pelayanan publik dalam proses pemberian layanan pembuatan terhadap administrasi kependudukan termasuk akta kelahiran kepada masyarakat, karena memicu atau adanya acuan untuk melaksanakan tugas dan kewajiban instansi yang bersangkutan.

\section{Faktor Penghambat}

Faktor penghambat secara internal sebagai berikut.

\section{Sumber Daya Manusia}

Dalam hal ini pegawai dituntut untuk memiliki kemampuan, pengetahuan, pendidikan dan keahlian untuk dapat melaksanakan pekerjaan, bukan hanya pengalaman sumber daya manusia yang diperlukan namun kemampuan, pengetahuan, pendidikan dan keahlian yang dimiliki sumber daya manusia juga menjadi modal awal dalam melaksanakan tugasnya untuk memberikan pelayanan yang terbaik oleh aparatur dengan melihat keinginan dan kebutuhan masyarakat.

\section{Kedisiplinan Petugas}

Dalam pelayanan di unit ini penerapan kedisiplinan masih agak sulit diterapkan, hal ini sudah disepakati bersama untuk waktu jeda ishoma (istirahat, salat, makan) siang dari pukul 12.00-14.00 WIB dan seharusnya tepat pukul 14.00 WIB pegawai harus sudah berada di tempat untuk melanjutkan pekerjaannya.

Hasil wawancara pada 10 Maret 2019 dengan beberapa warga masyarakat yang datang di UPTD Mollo Utara: 
"Saya lihat memang sering saya dengar keluhan dari masyarakat terkait hal ini, katanya masih banyak pegawai yang belum datang pada jam istirahat berakhir dan kadang masih ada pegawai pegawai yang tidak berada di tempat pada saat jam kerja, hal ini selalu kami evaluasi dan akan kami beri teguran pada pegawai yang telat."

Dari wawancara dengan Kepala UPTD Kependudukan dan Pencatatan Sipil Kecamatan Mollo Utara, dapat di ketahui bahwa masih dijumpai pegawai yang telat datang setelah ishoma dan pegawai ataupun aparat yang sering tidak berada di tempat saat jam kerja sehingga menyebabkan masyarakat harus menunggu untuk mendapatkan pelayanan. Pegawai yang berada di kantor saat jam kerja juga menjadi faktor penghambat dalam proses pelayanan pembuatan akta kelahiran, selain itu tidak adanya pegawai di kantor saat jam kerja sehingga menyebabkan masyarakat harus menunggu untuk mendapatkan pelayanan.

\section{Kesopanan dan Keramahan Petugas}

Kesopanan dan keramahan petugas, yaitu sikap dan perilaku petugas dalam memberikan pelayanan kepada masyarakat secara sopan dan ramah serta saling menghargai dan menghormati. Sebagaimana penulis melakukan wawancara dengan Kepala UPTD Kependudukan dan Pencatatan Sipil Kecamatan Amanuban Tengah, pada 10 Februari 2019 beliau menjelaskan bahwa:

"Kalau masalah pelayanan yang diberikan oleh petugas kami menurut saya sudah cukup baik, di sini kami di tuntut adanya keramahtamahan antara pegawai terhadap masyarakat serta santun dalam bertutur kata kepada pelanggan atau masyarakat. Kami tidak pernah membedakan antara masyarakat satu dengan masyarakat lainnya semua mendapatkan pelayanan yang sama."
Dari hasil wawancara dengan Kepala UPTD Kependudukan dan Pencatatan Sipil Kecamatan Amanuban Tengah Wawancara dengan salah satu masyarakat yang mengurus Akta Kelahiran di Kantor UPTD Kependudukan dan Pencatatan Sipil, Tanggal 10 Februari 2015 dapat diketahui bahwa petugas yang ada di Disduk ini sudah memberikan pelayanan yang terbaik di mana petugas sudah memperlihatkan sikap yang baik kepada masyarakat sehingga masyarakat atau pemohon merasa senang dengan perilaku yang diberikan.

"Menurut saya perlakuan petugas kepada masyarakat dalam memberikan pelayanan sudah cukup baik, walaupun terkadang masih ada perlakuan yang kurang menyenangkan bagi kami seperti bila kami ingin bertanya terkadang petugas acuh tak acuh terhadap pengakuan kami. Hal ini membuat kami kesal kepada petugas sehingga kami memilih diam. Mungkin itu hanya berlaku bagi petugas yang lagi ada masalah pribadi, sehingga kami berpikir bahwa petugas itu antara ya dan tidak niat untuk bekerja."

Dari hasil wawancara dengan salah seorang warga yang mengurus akta kelahiran masih ditemui keluhan masyarakat terhadap ketidakdisiplinannya petugas dalam menjalankan tugas. Hal ini dapat dilihat dari keterlambatan petugas datang ke kantor, dan sering tiadanya petugas di tempat tugas pada saat jam kerja berlangsung sehingga masyarakat yang butuh pelayanan harus menunggu dulu untuk mendapatkan pelayanan dari petugas.

\section{Kepemimpinan}

Alasan ini diperkuat oleh staf UPTD Kependudukan dan Pencatatan Sipil Kecamatan sebagaimana diwawancarai salah seorang Staf UPTD Kependudukan dan Pencatatan Sipil Kecamatan, 10 Februari 2019: 
“Kepala UPTD Kependudukan dan Pencatatan Sipil Kecamatan sebenarnya adalah seorang yang tegas dan keras. Namun untuk hal hal seperti ini memang tidak pernah memberikan teguran, tetapi sebenarnya ini tidak juga bisa disalahkan beliau, karena moto itu sudah ada hanya kami yang mungkin kurang mematuhi dan kurang menyadari akan hal itu. Untuk ke depannya kami akan usahakan melakukan moto 3"S" ini."

Dari hasil kutipan wawancara dengan salah satu Staf UPTD di atas dapat kita ketahui bahwa kepala UPTD Kecamatan adalah seorang yang tegas namun dalam beberapa hal tidak ada memberikan teguran. Hal ini membuktikan bahwa pemimpin belum cukup tegas dalam memimpin Kantor UPTD Kependudukan dan Pencatatan Sipil Kecamatan dan harus lebih tegas lagi setidaknya dapat memberikan teguran atau berupa sanksi terhadap pegawai yang bersikap tidak disiplin terhadap standar dan aturan yang telah dibuat.

\section{Sarana dan Prasarana}

Semua UPTD kependudukan Kecamatan harus bisa melengkapi sarana dan prasarana. Sejauh ini fasilitas yang ada harus diakui bahwa memang belum lengkap, namun masih dengan inisiatif aparat yang ada maka kekurangan alat-alat penting lainnya dapat diatasi, fasilitas kerja yang berhubungan dengan teknologi juga merupakan salah satu unsur yang penting namun belum ada, sehingga hal ini belum meningkatkan semangat kerja yang dimiliki oleh setiap UPTD, sebab apabila dengan dimilikinya berupa aplikasi validasi pangkalan data maka semangat kerja baik dapat merangsang dan menyenangkan serta menghapus kebosanan dalam diri individu dalam kegiatan sehariharinya.
Faktor penghambat secara eksternal sebagai berikut.

\section{Perkembangan Teknologi}

Teknologi yang dimaksud dalam inovasi pelayanan akta kelahiran Disdukcapil Kabupaten TTS belum dapat terlaksana secara online sementara semua daerah di pelosok tanah air telah memiliki aplikasi secara online dan masyarakat dengan mudah mengaksesnya. Memang sangat mudah namun untuk memvalidasinya yang agak sulit adalah pelaksanaan pelayanan secara online dan jaringan/koneksi internet.

Teknologi menjadi salah satu faktor penghambat dalam pelayanan yang dilakukan oleh Disdukcapil. Karena sistem yang terpusat mengakibatkan juga koneksi jaringan terkadang mengalami gangguan. Apabila dari Pusat mengalami gangguan maka otomatis di daerah pun juga akan ikut terganggu.

\section{Kesadaran Masyarakat}

Kesadaran masyarakat untuk memperbarui dokumen kependudukan ketika sudah pindah masih rendah. Selain rendahnya kesadaran masyarakat, banyak orang tua yang tidak berupaya agar anaknya harus mendapatkan akta kelahiran bahkan menganggarkannya sebagai kebutuhan bukan kewajiban, bahkan apabila ada kasus perceraian dan juga pindah alamat tidak melapor sehingga bisa memperbaharui data kependudukannya. Karena banyak kasus anak dititip ke Kartu Keluarga orang tuanya atau saudaranya sebagai akibat belum nikah sehingga tidak mengurusnya secara mandiri.

Keadaan tersebut hanya dilakukan untuk anak melengkapi persyaratan pendaftaran sekolah agar bisa menjadi prioritas diterima di sekolah yang diinginkan. Tentu dengan beberapa terobosan yang dipakai oleh UPTD maka ke depannya semua warga akan diprioritaskan untuk memperoleh dokumen kependudukan secara lengkap. 


\section{SIMPULAN}

Efektivitas pelayanan administrasi kependudukan termasuk akta kelahiran yang dilakukan pada setiap UPT Dinas Kependudukan dan Pencatatan Sipil Kabupaten TTS, telah dilaksanakannya secara efektif dan efisien sesuai SOP yang ada, sekalipun sangat melelahkan warga masyarakat harus menunggu dengan waktu yang tidak menentu, namun dengan harapan pasti akan diperolehnya, sebab semua data yang dihimpun dari setiap UPTD akan divalidasinya pada kantor induk. Sebagai faktor pendukung, yakni setiap layanan digratiskan sehingga segala antrean tidak berdampak pada saling menuntut. Selain itu, setiap administrasi kependudukan menjadi kebutuhan sehingga segala daya dapat dilakukan untuk memperolehnya, oleh karena itu bagi yang tidak suka berantrean pasti menggunakan orang lain untuk mengurusnya, dengan persyaratan yang dibutuhkan. Sedangkan faktor penghambat secara internal, yaitu masih banyak kekurangan dalam hal sarana dan prasarana, tenaga aparat yang masih kurang, termasuk hal sosialisasi sehingga warga harus datang bisa mengurus administrasi kependudukannya. Belum lagi anggaran yang diberikan melalui Pagu anggaran dinas sangat kecil sebab semua UPTD dalam wilayah Kabupaten TTS mendapatkan jatah tiap tahun sebanyak 277 juta lebih yang dibagi dalam lima wilayah sementara medan jalan setiap desa tidak sama, artinya hal ini menjadi kendala dalam hal sosialisasi.

\section{DAFTAR PUSTAKA}

Angkat, K.M., Kadir, A., dan Isnaini. 2017. Analisis Pelayanan Administrasi Kependudukan pada Dinas Kependudukan dan Pencatatan Sipil Kabupaten Dairi. Jurnal Administrasi Publik (JAP), Vol. 7, No. 1, Juni 2017, hlm. 33-48

Arikunto, S. 2013. Prosedur Penelitian Suatu Pendekatan Praktik. Jakarta: Rineka Cipta
Asmar, A.R. 2017. Pelayanan Publik di Bidang Administrasi Kependudukan (Studi Kasus Kota Makassar). Jurisprudentie, Vol. 4, No. 1, Juni 2017, hlm. 1-24

Atmadjati, A. 2018. Layanan Prima dalam Praktik Saat Ini, Ed.1, Cet. 1. Yogyakarta: Deepublish

Denhardt, J.V. dan Denhardt, R.B. 2016. The New Public Service: Serving, Not Steering. New York: M.E. Shape

Dwiyanto, A. 2008. Mewujudkan Good Governance melalui Pelayanan Publik. Yogyakarta: Gajah Mada University Press

Dwiyanto, A. 2010.Manajemen Pelayanan Publik: Peduli, Inklusif, dan Kolaboratif. Yogyakarta: Gajah Mada University Press

Ekowanti, M.R.L. 2017.Kemitraan dalam Otonomi Daerah. Malang: Inteligensia Media

Humaedi, M.A. 2016. Etnografi Bencana: Menakar Peran Para Pemimpin Lokal dalam Pengurangan Resiko Bencana, Cet. 1. Yogyakarta: LkiS

Junaidi. 2015. Implementasi Electronic Government untuk Penyelenggaraan Pelayanan Administrasi Kependudukan. Reformasi, Vol. 5, No. 1, Tahun 2015, hlm. 169-182

Moleong, L.J. 2013. Metode Penelitian Kualitatif. Bandung: Remaja Rosdakarya

Miles,M.B Huberman,A.M, dan Saldana.J.2014. Qualitative Data Analysis, A Methods Sourcebook, Edition 3.USA: Sage Publications. Terjemahan Tjetjep Rohindi Rohidi, UI-Press

Nurcholis, H. 2007. Teori dan Praktik Pemerintahan dan Otonomi Daerah. Jakarta: Grasindo

Pananrangi, A.R. dan Murlinah. 2017. Etika Birokrat. Makassar: CV Sah Media

Pawito. 2008. Penelitian Komunikasi Kualitatif. Yogyakarta: LkiS

Rai, I.G.A. 2008. Audit Kinerja pada Sektor Publik: Konsep, Praktik, dan Studi Kasus. Jakarta: Salemba Empat

Rohman, D.F., Hanafi, I., dan Hadi, M. 2013. Implementasi Kebijakan Pelayanan 
Administrasi Kependudukan Terpadu (Studi pada Dinas Kependudukan dan Catatan Sipil Kota Malang). Jurnal Administrasi Publik (JAP), Vol. 1, No. 5, Tahun 2013, hlm. 962-971

Sedarmayanti. 2009. Sumber Daya Manusia dan Produktivitas Kerja. Bandung: Mandar Maju

Selpianti. 2016. Pelayanan Akta Kelahiran oleh Dinas Kependudukan dan Pencatatan Sipil Kota Batu. JISIP: Jurnal Ilmu Sosial dan Ilmu Politik, Vol. 5, No. 2, Tahun 2016, hlm. 76-78

Sugiyono. 2012. Metode Penelitian Kuantitatif, Kualitatif, dan R\&D. Bandung: Alfabeta

Sukardi. 2010. Metodologi Penelitian Pendidikan: Kompetensi dan Praktiknya. Jakarta: Bumi Aksara

Sumadiono, W. 2018. Pedoman Umum Organisasi dan Administrasi Rukun Warga Rukun Tetangga. Yogyakarta: Deepublish

Suyatno, et.al. 2011. Good Public Services, Antara Good Governance dan Harapan Rakyat. Buletin Bung Karno: Media Informasi Perpustakaan Bung Karno, Vol. 3, No. 3, Tahun 2011, hlm. 4-9

Tarigan,I.J. 2017. Peran Badan Narkotika Nasional dengan Organisasi Sosial Kemasyarakatan dalam Penanganan Pelaku Penyalahgunaan Narkotika. Yogyakarta: Deepublish
Wilson,W. 1887. The Study of Administration. Political Science Quarterly, Vol.2, No. 3 Tahun 1887, hlm. 197-222.

Widi, Restu Kartiko. 2010. Asas Metodologi Penelitian. Yogyakarta: Graha Ilmu

Yusriadi. 2018. Reformasi Birokrasi dalam Pelayanan Publik. Yogyakarta: Deepublish

\section{Peraturan Perundang-Undangan}

Keputusan Menteri Pendayagunaan Aparatur Negara Nomor: 63/KEP/M. PAN/7/2003 tentang Pedoman Umum Penyelenggaraan Pelayanan Publik

Peraturan Menteri Dalam Negeri Republik Indonesia Nomor 120 Tahun 2017 tentang Unit Pelaksana Teknis Dinas Kependudukan dan Pencatatan Sipil Kabupaten/Kota

Peraturan Bupati Timor Tengah Selatan Nomor 15 Tahun 2011 tentang Organisasi dan Tata Kerja Pelaksana Teknis Dinas Kependudukan dan Pencatatan Sipil di Kecamatan. 